\title{
The Collaboration Of Pancasila And Civic Education Teacher In Subject Teacher Consultation Forum (MGMP) At Junior High School
}

\author{
Afrizilna ${ }^{1)}$, Maria Montessori ${ }^{2)}$ \\ Master Program (S2) of Pancasila and Civic Education (PPKn), Faculty of Social Sciences - State \\ University of Padang, Indonesia ${ }^{1,2)}$ \\ afrizilna71@gmail.com ${ }^{1)}$, mariamontessori@ fis.unp.ac.id ${ }^{2)}$
}

\begin{abstract}
The subject teacher meeting is a forum formed by the government to facilitate collaboration and collaboration of subject teachers in solving various learning problems and being a forum for developing teacher professionalism. This article aims to analyze and describe the collaboration of PPKn teachers in State Junior High School Sawahlunto City, West Sumatra Province, and the problems that occur in it. This research was conducted with a qualitative approach. Respondents were selected from elements of PPKn teachers who were members of the MGMP State Junior High School Sawahlunto City, MGMP administrators, school principals, and the Education Office of Sawahlunto City. Data analysis followed the stages of qualitative data analysis Miles \& Huberman; data reduction, data display, and conclusion drawing. The results of the study show: (1) the problem of weak teacher collaboration in MGMP is related to the impact of the non-formal relationship between teachers, which is too dominant but also to the discipline and teachers motivation. (2) The expected impact of the implementation of MGMP PPKn State Junior High School is an increase in teacher competence in implementing learning which in the end also improves student learning outcomes. However, this target has not been fully achieved because the behavior and average learning outcomes of students are still low. (3) There is no specific strategy to increase collaboration between teachers carried out by the management in the MGMP PPKn forum for State Junior High School Sawahlunto City.
\end{abstract}

Keywords: Collaboration, Deliberation, Pancasila and Civic Education (PPKn).

\begin{abstract}
Abstrak. Musyawarah guru mata pelajaran merupakan wadah yang dibentuk pemerintah untuk memfasilitasi kerjasama dan kolaborasi guru mata pelajaran dalam memecahkan berbagai persoalan pembelajaran sekaligus menjadi wadah pengembangan professionalisme guru. Artikel ini bertujuan untuk menganalisis dan mendeskripsikan kolaborasi guru PPKn SMP Kota Sawahlunto Provinsi Sumatera Barat serta problematika yang terjadi di dalamnya. Penelitian ini dilakukan dengan pendekatan kualitatif. Responden dipilih dari unsur guru PPKn yang menjadi anggota MGMP SMP Negeri Kota Sawahlunto, pengurus MGMP, kepala sekolah, dan Dinas Pendidikan Kota Sawahlunto. Analisis data mengikuti tahapan analisis data kualitatif Miles\& Huberman; reduksi data, display data, dan penarikan kesimpulan. Hasil penelitian menunjukkan: (1) Masalah lemahnya kolaborasi guru dalam MGMP tidak hanya berkaitan dengan dampak hubungan nonformal antar guru yang terlalu dominan tetapi juga karena faktor disiplin dan motivasi guru. (2) Dampak yang diharapkan dari pelaksanaan MGMP PPKn SMP Kota Sawahlunto adalah meningkatnya kompetensi guru dalam melaksanakan pembelajaran yang pada sasaran akhirnya juga meningkatkan hasil belajar peserta didik. Namun target ini belum sepenuhnya tercapai karena perilaku dan rata-rata hasil belajar peserta didik masih rendah. (3) Tidak ada strategi khusus yang dilakukan untuk meningkatkan kolaborasi antar guru yang dilakukan pengurus dalam forum MGMP PPKn SMP Kota Sawahlunto.
\end{abstract}

Kata Kunci: Kolaborasi, Musyawarah, PPKn. 


\section{INTRODUCTION}

The teacher himself can essentially make efforts to increase teacher competence, for example, by attending continuing lectures, attending training, attending seminars, attending training, reading professional books, etc. In addition, this effort is also supported by the government by providing facilities for teachers to participate in and carry out activities in a Subject Teacher Consultation forum (MGMP). Based on the guidelines for the development of KKG and MGMP issued by the director-general of improving the quality of educators and education personnel, the Director-General of Higher Education of the Ministry of National Education in 2010 as well as Minister of Religion Regulation Number 60 of 2015 articles 47A and 47B, states that MGMP is the most appropriate forum to improve teacher competence and given credit score recognition for teachers who will apply for promotion. Therefore, the implementation of MGMP must be carried out in a structured and directed manner so that these activities become a vehicle for developing quality, independent and sustainable teacher professionalism. In the MGMP forum, teachers can also share knowledge and share experiences experienced during their activities in their respective workplaces. Thus the teacher will be increasingly rich in expertise in completing learning at school, rich in knowledge about the material to be taught to students, and it is hoped that the teacher will be confident and improve performance in carrying out, which is expected to ultimately improve student learning outcomes in the classroom.

Once the importance of the MGMP forum for improving teacher competence, it is necessary to pay close attention to the activities carried out in the forum. The MGMP forum is no different from other forums or social organizations. Where a social organization is built on the cooperation of its members, according to some expert opinions, it can be concluded that in an organization, there is an attachment informal social relationships that work together to achieve common goals (Hasibuan (2013: 24), Waldo in his book Silalahi (2011:124), Weber quoted by Silalahi (2011: 124). Although the MGMP is a social organization, there are differences, among others, if other social organizations are formed by the community or interested parties. In contrast, the Subject Teacher Consultation (MGMP) is formed by the government, whose members consist of certain professions, namely the teaching profession. Where the implementation of activities is regulated by the government. MGMP forums are non-structural in an area to collaborate or work together by exchanging experiences to improve teacher abilities and improve the quality of learning. Thus, it can be said that the MGMP forum is an intellectual forum attended by professional teachers who can produce quality programs to support the improvement of the quality of 
education. An organization that is recognized for its implementation by the government and the credit score for teachers who will be promoted. In addition, the MGMP can be used by teachers as a forum to collaborate in responding to the demands of 21 st-century student learning skills.

Related to the results of the initial observations that the author conducted on 11 junior high school MGMPs in the West Sumatra region showed that $63.6 \%$ of the activities of participants in the MGMP were collaborating or collaborating. The collaboration carried out by the participants is participating in activities during the MGMP, starting from preparing the program, implementing the program, evaluating and documenting the results of the MGMP program. In detail, it can be seen that $43 \%$ of participants participated in developing the MGMP program, $43 \%$ of participants participated in implementing the program, $43 \%$ participated in evaluating program implementation, $43 \%$ of participants documented the results of MGMP activities while the attendance of participants in the MGMP implementation was shown in the figure of $71 \%$. As a comparison, the researchers also took data from 8 MGMPs in the city of Sawahlunto as many as $50 \%$ of participants participated in compiling the MGMP program, as many as $63 \%$ of participants indicated that they participated in implementing the program, as many as $62 \%$ of participants participated in evaluating program implementation, while $50 \%$ of participants participated in documenting the results of MGMP activities. And based on the results of preliminary observations specifically for PPKn subjects, it was found that $50 \%$ of participants participated in compiling the MGMP program, $50 \%$ of participants indicated that they participated in implementing the program, 50\% of participants participated in evaluating the implementation of the program, and $50 \%$ of participants participated in documenting the results of MGMP activities, while attendance showed numbers. $75 \%$. This data is supported by the results of observations made by researchers that when the MGMP schedule there were still many teachers who did not attend the MGMP for various reasons, came not on time, and even if they were present, they just sat, remained silent or just had a reunion, did not discuss the problems when conducting activities. Learning process faced in their respective schools and More reviews of things outside the problem of learning. Besides, many MGMP members are old, so the enthusiasm to increase their competence decreases. To make matters worse, there is a culture in teaching where seniors are better than juniors. Then there is an assumption that the management is usually held by younger teachers in age, thus creating barriers to sharing. Furthermore, the MGMP activities were only carried out for a few hours in terms of the implementation 
process. There was not enough time to share, and these activities did not provide maximum results. From these data, it can be concluded that the involvement of MGMP participants in collaborating is still low.

Several previous research results show a relationship between collaboration between members and the achievement of MGMP goals. And some expert opinions discussing collaborating stated that in collaborating, there are certain activities shown by each member to achieve common goals (Abdulsyani (1994; 156), Abdulsyani, Roucek, and Warren (1994; 159). And in collaborating, there is a division of tasks. Everyone does the job that is their responsibility to achieve a common goal (Hadari Nawawi (1984: 07). So there is indeed a link between collaboration and the goals to be achieved within an organization. In connection with the data above, how is collaboration carried out by these professional teachers in implementing MGMP, especially MGMP PPKN at the State Junior High School level in the city of Sawahlunto?

\section{RESEARCH METHODS}

This article results from qualitative research to look at the phenomenon more broadly and in-depth according to what happened and developed in the social situation under study, namely the study of the collaboration of Civics Teachers in improving the quality of learning at State Junior High School.This writing was intended to analyze and describe the implementation of PPKn teacher collaboration, especially MGMP in Sawahlunto. MGMP activities could improve the quality of Civics learning at the junior high school level Sawahlunto City. According to Moleong (2005:3), "qualitative research is a research procedure that produces descriptive data in the form of written or spoken words from people and observed behavior." The research location in this study was the City of Sawahlunto, West Sumatra Province. The city of Sawahlunto was chosen as the location for this research because it had nine public junior high schools whose teachers were actively involved in the MGMP every Friday. Informants in this study were determined by purposive sampling. According to Bungin (2003:53), purposive sampling is to determine informants with certain considerations which are considered to be able to provide maximum data. Based on the purposive sampling technique, the informants in this study were: PPKn Subject Teachers at the State Junior High School level in Sawahlunto City, MGMP Management at the Sawahlunto City Junior High School level, Elements of the Education Office. This study used three data collection techniques, namely, observation, interview, and documentation study. To test the validity of the data in this study, the researcher used triangulation of data collection techniques and increased persistence. According to Sugiyono (2009) "Triangulation techniques in testing the validity (credibility) of the data can be done by 
checking the data to the same research source or informant with different techniques." To analyze data from research interviews, researchers used interactive model data analysis techniques. According to Miles and Huberman quoted by Sugiyono (2011: 278), "activities in qualitative data analysis are carried out interactively and continuously until complete so that the data is saturated, namely data reduction, data display conclusion drawing/verification".

\section{DISCUSSION}

Collaboration is a form of interaction and cooperation between individuals or between groups in completing tasks with the same substance of goals. One of the forums for teacher collaboration in Indonesia is the MGMP, a forum for continuous teacher professional development. This MGMP is a form of long-term collegial supervision that aims to increase competence. Vernez et al. (2016) mention that long-term training strategies are helpful in improving teachers' abilities effectively in providing better curriculum content and lesson guidance, starting from planning, learning practices, and other curriculum approaches. One of the main advantages of collaborative relationships over other school improvement efforts is that collaborative relationships allow schools to jointly build improvements around their individual needs, rather than using other programs from other schools that may not be contextualized appropriately. There is no excellent activity without collaboration. The close relationship between individuals is caused because these individuals have similarities in thinking and always live in groups to overcome student and family problems. The existence of a common goal makes individuals join to achieve a common goal.

The study results indicate a lack of effective and productive collaboration in MGMP PPKn State Junior High School Sawahlunto City, which is indicated because there are too many informal activities in collaboration. Although qualitatively, it does not mean that this does not impact all, but it will not be so significant to solve the competence and professionalism of teachers in carrying out their duties. Although the collaboration began with the existence of "Comprehensive collaboration begin because individuals reach out to like-minded people and groups to address issues that affect children and families"

Weak coordination among fellow MGMP management so that the administration is not solid, less programmed activities seems to have no good planning. So that, there is no perceived frequency of routine activities, lack of sensitivity of administrators to new educational issues, low participation of teachers MGMP members are involved in activities (Rohiat.2012:14). This should be a study for the management of MGMP PPKn 
State Junior High School Sawahlunto City to find a solution, both theoretically and practically immediately. Ignoring this problem will undoubtedly slow down the increase in teacher professionalism which ultimately also impacts student learning outcomes. Collaboration between teachers is also one of the programs in the independent learning curriculum. This is because learning is based on collaboration and interaction between teachers and teachers in the long term. Peer teaching is one way to increase the relevance of teacher competence. Teachers learning with fellow teachers can foster empathy and trust in fellow teachers who have played a role and interacted in the teaching process in various classes. In addition, teachers will know and learn the challenges of teaching in different classes.

Therefore, a strategy to increase teacher collaboration is needed, which strategic steps are taken by the management to increase teacher collaboration in the MGMP PPKn forum for State Junior High School Sawahlunto City through various activities. The results of data analysis can be concluded that there is no specific strategy taken to increase collaboration between teachers carried out by the management in the MGMP PPKn forum for State Junior High School Sawahlunto City. All activities are carried out based on the program that has been prepared. MGMP management must develop programs with activities that can increase collaboration between teachers in solving learning problems. The results of data analysis also showed that teachers felt that the discussions that developed in MGMP activities did not address the actual issues faced by teachers.

Teacher collaboration in any professional development forum, including MGMP will have an impact on students. So schools need to develop collaborative programs for teachers. As part of essential personnel in schools, teachers have great potential to achieve school goals. Improving teacher competence through collaborative programs is an integral part of the success of education in schools. In this case, collaboration is a form of the ability to cooperate is a behavior that helps two or more people to enable work together and function well in the process. Johnson \& Johnson (1991) defines "cooperation as working together to accomplish shared goals." A person can cooperate if that person and others work together to achieve the same goal. There are two important elements in every collaboration, namely the similarity of goals and positive dependence among the individuals who are members of the cooperative group, as described by Hill \& Hill that "the two essential elements in any cooperative activity are goal similarity and positive interdependence" (Hill \& Hill, 1993: 7).

As a simple analogy, a teacher with good competence will carry out the learning process effectively. The effectiveness of 
learning will affect students' learning outcomes, and increasing student learning outcomes will increase the effectiveness of schools, which will also describe an increase in the quality or success of the school. Whereas teachers progress in terms of performance but on a personal level, teachers also seem to benefit from feeling less isolated, more motivated, and have better morale (Vangrieken et al.: 2015). The target after the implementation of the MGMP is to increase teacher competence in implementing learning which in the end also improves student learning outcomes. However, this target has not been fully achieved because students' behavior and average learning outcomes are still low. The purpose of holding the MGMP according to the MGMP Guidelines consists of general objectives and specific objectives. The general aim of the MGMP is to develop creativity and innovation in improving teacher professionalism. At the same time, some of the particular goals of the MGMP are: First, to broaden the insight and knowledge of subject teachers to realize effective and efficient learning. Second, developing a conducive classroom culture as a place for fun, excitement, and educating students. Third, to build cooperation with the community as teacher partners in carrying out the learning process.

Regarding the impact of teacher collaboration on the MGMP forum stated by the principal in the interview above, it can be concluded that some stated that it was not too significant, and some noted that the existence of this PPKn MGMP helped them. Based on this, it is assumed that there are differences in competence between teachers so that the impact of the implementation of MGMP on the success of learning in schools is different. Besides, the characteristics of students and schools are also possible causes of different learning outcomes for students who are fostered by teachers who are members of the PPKn MGMP State Junior High School Sawahlunto City. Teacher collaboration through MGMP activities needs to be optimized with the hope that it will create an increase in teacher professionalism through various efforts, namely optimizing PPKn MGMP activities that are tailored to the needs of teachers and students in the field, including making learning tools, deepening material, and making questions, and so on that are very helpful for teachers in solving problems and difficulties encountered while carrying out their main duties as teachers in schools; continuous teacher professional development, such as holding teacher competency development workshops, seminars, comparative studies, best practice, real teaching, peer teaching, writing scientific papers, and Classroom Action Research; motivating the importance of increasing professionalism to improve teacher competence for improving the quality of 
performance as professional teachers (Rimaulina, 2013).

\section{CONCLUSION}

The collaboration carried out by PPKn teachers at the State Junior High School Sawahlunto City is almost all activities in the MGMP forum because MGMP is a place for supervising the professional development of teachers with collegial groups. The problem of weak teacher collaboration is indicated not only related to the impact of excessive nonformal relationships between teachers but also on teacher discipline and motivation factors. The expected impact of implementing the MGMP PPKn State Junior High School Sawahlunto City is an increase in teacher competence in implementing learning, which also improves student learning outcomes. However, this target has not been fully achieved because students' behavior and average learning outcomes are still low. The management has carried out no specific strategy to increase collaboration between teachers in the MGMP PPKn forum for State Junior High School Sawahlunto City. All activities are carried out based on the program which has been prepared.

\section{REFERENCES}

[1] Aditya Nugroho Widiadi1, Indah Wahyu Puji Utami. (2016). Pembelajaranu Pengetahuan Sosial Pada Sekolah Menengah Pertama. Vol.1 No.2 Oktober 2016 P ISSN 2503 1201, E ISSN 2503 - 5347

[2] Afrizal, (2008). Penelitian Kualitatif. Jakarta: Kencana Prenada Media.
[3] Anwar.Us.Kasful. (2015). Jaminan Mutu dan Upaya Pengembangan Profesionalitas Guru Pada Abad Pengetahuan.JurnalNur El-Islam.

[4] Arifin, I. (2000). "Profesionalisme Guru: Analisis Wacana Reformasi Pendidikan

[5] Arikunto, Suharsimi. (1993). Prosedur Penelitian Suatu pendekatan Praktek.Jakarta: Rineka Cipta

[6] Armiatin, Dwi Septiwihartini, Yusdin Gagaramusu. (2017). Meningkatkan Hasil Belajar Siswa Pada Mata Pelajaran PKn Di Kelas V SdN No. 4 Pangalasiang Melalui Bimbingan Kerja Kelompok. Jurnal Kreatif Tadulako Online Vol. 3 No. 4ISSN 2354-614X

[7] Asmarani, Nuraeni. (2014). Peningkatan Kompetensi Profesional Guru di Sekolah Dasar. Jurnal Administrasi Pendidikan.Volume 2 Nomor 1, Juni 2014.

[8] Bambang Sumantri, (2014). Peningkatan Kualitas Pembelajaran PKn melalui Model Pembelajaran Kooperatif pada Siswa SMP. Media Prestasi Jurnal Ilmiah STKIP PGRI Ngawi Vol.13 No. 1(2014) p20 - p30 Pendidikan. Cakrawala Pendidikan.

[9] D. Mardapi, (2012). Strategi Meningkatkan Profesionalisme Guru.Makalah pada

[10] Da'I, (2017). Peningkatan Pembelajaran PKn Melalui Penerapan Strategi Pembelajaran Kolaborasi Pada Siswa SMP.Didaktis: Jurnal Pendidikan dan Ilmu Pengetahuan Vol.17 No.1 dalam Era Globalisasi"'.SimposiumNasional Pendidikan di UniversitasMuhammadiyah Malang, 25-26 Juli 2001.

[11] Dantes.Nyoman. (2004). Profesionalisme Guru Dalam Kaitannya Dengan Pelaksanaan Kurikulum Dan Implementasinya Pada Model Asesmen Berbasis Kompetensi Makalah (disampaikan pada Seminar tentang profesionalisme Guru di Kabupaten Gianyar, tanggal 27 Nopember 2004).

[12] Dwi Iriyani, (2016). Penerapan Pembelajaran Yang Berbasis Pendekatan Scientific Bagi Guru. Civic-Culture : Jurnal Ilmu Pendidikan PKn dan Sosial Budaya" ISSN 2579-9924 ISSN 2579-9878. 
[13] Ellis, M., Lock, G., \& Lummis, G. (2015). Parent-Teacher Interactions: Engaging with Parents and Carers. Australian Journal of TeacherEducation, 40(5).

[14] Ervin F. Sparapani, David Callejo Perez, Jonathon Gould, (2014). A Global Curriculum? Understanding Teaching and Learning in the United States, Taiwan, India, and Mexico.

[15] Hani, T. H. (2001). Manajemen Personalia dan Sumber Daya Manusia. Yogyakarta: BPFE.

[16] Harsh R. Shah and Luis R. Martinez. (2016). Current Approaches in Implementing Citizen Science in the Classroom. Journal ListJ Microbiol Biol Educv.17(1)PMC4798802.

[17] Johnson, D.W, \& Johnson, R.T.(1991). Learning Together and Alone: Cooperative, Competitive, and Individualistic. ThirdEddition. Engelwood Cliffs, NJ: Prentice Hall

[18] Konvensi Nasional PendidikanIndonesia (KONASPI) VIII Tahun 2016.

[19] Mahsunah. Dian. dkk. (2012). Kebijakan Pengembangan Profesi Guru. Badan Pengembangan Sumber Daya Manusia Pendidikan dan Kebudayaan danPenjaminan Mutu PendidikanKementerian Pendidikan danKebudayaan.

[20] Maleong, (2005). Metode Praktis Penelitian Deskriptif Kualitatif Bandung : Rosdakarya

[21] Masrukin, Muhammad. (2009). Upaya Pembaharuan Pendidikan Menuju Masyarakat Madani dalam Warta IKIP.Yogyakarta: IKIP.

[22] Muhlison, (2014). Guru Profesional (Sebuah Karakteristik Guru Ideal Dalam Pendidikan Islam). Jurnal Darul ' Ilmi Vol. 02, No. 02 Juli.Ondi, S., \& Aris, S. (2010). Etika Profesi Keguruan. Bandung: Rafika Aditama.

[23] Muhson, Ali. (2014). Meningkatkan Profesionalisme Guru: Sebuah Harapan, Jurnal Ekonomi \&Pendidikan, Vol, 2 No. 1 Agustus 2014.
[24] Nicoleta DuĞăä, E. R. (2014). Importance of the lifelong learning for professional development of university teachers - needs and practical implications. P r o c e d i a - S o c i a la nd B e havioral $\mathrm{S}$ c i e n ces 12 7, 801-806.

[25] Parry Graham, (2015). Improving Teacher Effectiveness through Structured Collaboration: A Case Study of a Professional Learning Community. ISSN: (Print) 1940-4476 (Online) Journal homepage:

http://www.tandfonline.com/loi/umle20. RMLE Online- Volume 31, No. 1 Pendidikan. Jurnal Pendidikan Islam, Jurusan Tarbiyah, 2 Mei 2005.

[26] Permenpan. (2009). Peraturan MenteriNegara Pendayagunaan Aparatur Negaradan Reformasi Birokrasi Nomor 16Tahun 2009 tentang Jabatan FungsionalGuru dan Angka Kreditnya. Proses Belajar Mengajar. Karya Ilmiah. Klaten: Kandep Dikbud.

[27] R. Mursid, Eko Wahyu Nugrahadi, Sahat Siagian, (2014). Model-model Based Leraning Entrepreneurship Development Efforts In The Formation of Character. International Journal of Education and Research Vol. 2 No. 11 November ISSN: 2201-6333 (Print) ISSN: 2201-6740 (Online) www.ijern.com.

[28] Rahmat, W. (2016). Penerapan kabaminangkabau sebagai media pelestarianbahasa amai (ibu) dan kesusastraan dalampendidikan literasi di minangkabau.Jurnal Iptek Terapan, 4(4), 236-241.

[29] Rian Anggara dan Umi Chotimah, (2012). Penerapan Lesson Study Berbasis Musyawarah Guru Mata Pelajaran (MGMP) Terhadap Peningkatan Kompetensi Profesional Guru PPKn SMP Se-Kabupaten Ogan Ilir.Jurnal Forum Sosial, Vol. V, No. 02, September.

[30] Rimaulina Listian Fithaloka. (2013). Peranan Kinerja MGMP PKn dalam Meningkatkan Profesionalisme Guru SMP. Bandung: Universitas Pendidikan Indonesia. 
[31] Rohiat. (2012). ManajemenSekolah (Teori Dasardan Praktik). Bandung: Reflika Aditama

[32] Rohman, Arif. (2007). "pendidik dan pesertadidik", dalam Dwi Siswono dkk (ed,)Ilmu Pendidikan, Jogjakarta: UNYPress

[33] Rudy Gunawan. (2011). Implementasi Pengembangan Profesionalisme BagiGuru BersertifikatPendidik.Jurnal.Uhamka.

[34] Rusman.

(2010).

Model-Mode Pemebelajaran Mengembangkan Profesionalisme Guru. Ban-dung: Raja Grafindo Persada

[35] Sagala, H. Syaiful. (2009). Kemampuan Profesional Guru dan Tenaga Kependidikan, Bandung: Alfabeta.

[36] Sanaky.Hujair AH. (2005). Sertifikasi dan Profesionalisme Guru di era Reformasi

[37] Sandi, W. (2010). Pengembangan Bahan Workshop Lesson Study Serta Implementasi Oleh Guru Matematika di Madrasah Ibtidaiyah Negeri 1 Pangkalpinang.Tesis tidak diterbitkan. Palembang: Fakultas Keguruan dan Ilmu Pendidikan

[38] Sarbiran. (1997). 1-11 Menerawang PerguruanTinggi di Era Globalisasi dalam

[39] Saud, Udin Syaefudin. (2009). Pengembangan Profesi Guru. Bandung: Alfabeta.

[40] Shaleh, Abdul Rahman. (2006). Evaluasi HasilBelajar. Jakarta: Departemen Agama RI

[41] Slamet PH. (1991). Pendidikan Guru diIndonesia: Masalah dan Strategi Pemecahannya.Pidato Dies Natalis XXVIIIKIP Yogyakarta.

[42] Soedijarto. (2008). Seminar Nasional Tentang "Perlindungan Bagi Profesi Guru". Jakarta.

[43] Soewarni, E. (2004). Kebijakan Pedoman Pengembangan Profesi. Jakarta: Rajawali Press.

[44] Subadi, Tjipto. (2010) . Pendidikan Kewarganegaraan (Civic Education). Surakarta:
[45] Sudarno. dkk. (1998). Kreativitas Gurudalam CBS Menentukan Keberhasilan

[46] Sudja.I Nengah. (2013). Pembelajaran Demokratis Menuju Profesionalisme Guru.Jurnal Santiaji Pendidikan, ISSN20879016, Volume 3, Nomor 2, Juli 2013.

[47] Sudrajat, Ahmad. (2008). Lesson Study untuk Meningkatkan Proses dan Hasil Pembelajaran,

[48] Sugeng Bayu, W. (1997). "Patologi BirokrasiPendidikan" dalam Jurnal Kependidikan.Hal. 1-6.

[49] Sugiyono, (2009). Metode Penelitian Kuantitatif, Kualitatif dan $R \& D$, Bandung : Alfa Beta.

[50] Sukirman. (2006). Peningkatan Keprofesionalan Guru Melalui Lesson Study. Makalah disajikan dalam Pelatihan Lesson Study Bagi Guru Berprestasi dan MGMP MIPA SMP Seluruh Indonesia, Yogyakarta,26 November-10 desember 2006

[51] Supriadi.Oding. (2009). Pengembangan Profesionalisme Guru Sekolah Dasar. Jurnal Tabularasa PPS Unimed.Vol.6 No.1, Juni 2009.

[52] Susilo, dkk. (2009). Lesson Study Berbasis Sekolah Guru Konservatif Мепијu Guru Inovatif. Malang: Bayumedia Publishing

[53] Suwarna. (2004). Guru Profesional, VariabelInvestasi di Era Otonomi. Kedaulatan

[54] Syah,M. (2011). Psikologi Pendidikan denganPendekatan Baru.Bandung:Remaja Rosdakarya.

[55] Syaikuna. (2020). Kolaborasi Guru dalam MGMP sebagai Peningkatan Mutu Pendidikan di MTs Unggulan Pondok Pesantren Amanatul Ummah Pacet Mojokerto. Jurnal Pendidikan dan Pranata Islam (open accsess). Volume 11 Nomor 1 Maret 2020. p-ISSN:2086-9088, e-ISSN: 2623-0054.

[56] Tika, Marselinus. (2013). Sertifikasi danProfesionalisme Guru. 
[57] Titik Haryati, Noor Rochman, (2015). Peningkatan Kualitas Pembelajaran Pendidikan Kewarganegaraan Melalui Praktek Belajar Kewarganegaraan (Project Citizen). Jurnal Ilmiah CIVIS, Volume II, No 2, Juli

[58] Undang-undang Nomor. 20 Tahun 2003 tentang Sistem Pendidikan Nasional

[59] Undang-Undang Republik Indonesia nomor 14 tahun 2005 tentang Guru dan Dosen.

[60] Wijanarti, Novita. (2016) Evaluasi PencapaianStandar Pelayanan MinimalBerdasarkan Prinsip Good Governancedi Sekolah Dasar Negeri. Jurnal Manajemen Pendidikan Magister Manajemen Pendidikan FKIP Universitas Kristen Satya Wacana.Volume: 3, No. 2, Juli-Desember 2016.

[61] Wirawan, (2013). Teori-Teori Sosial dalam Tiga Paradigma. Jakarta: PT. Kharisma Putra Utama.

[62] Yuniwati, Muhsinatun Siasah. (2016). Peningkatan Kualitas Pembelajaran PPKn Melalui Penerapan Problem based Learning di SMP.Harmoni Sosial: Jurnal Pendidikan IPSp-ISSN: 2356-1807 e-ISSN:2460-7916

[63] Yusuf. Ahmad. (2016). Model-Model Pengembangan Profesionalisme Guru.

[64] Yusutria. (2017). Profesionalisme Guru Dalam meningkatkan Kualitas Sumberdaya Manusia.Jurnal Curricula Kopertis Wilayah $\mathrm{X}$ Vol 2, No. 1

[65] Zainal, A., \& Elham, R. (2007) Pengembangan Profesi. Bandung: Remaja Rosdakarya. 